and low-grade fruits, both syrups and wines being investigated. In 1934, fruit squashes were included in the programme, and with such success that in the following year production employing the Long Ashton methods was extended to the commercial scale. Even greater success has attended the researches on fruit syrups. The growing popularity of milk bars has resulted in a demand for various syrups as constituents of 'milk shakes'. For the last two years the Research Station has worked in close collaboration with a local firm producing these commodities. and syrups are now being sold on the large scale under the National Mark Scheme. A still more recent development has been the use of these syrups for aerated beverages, the high ascorbic acid content of the juices being an important feature in their favour. Wines made from English fruits have attractive characters and are of full alcoholic strength, but they are relatively expensive, and development on the commercial scale is not expected to be so rapid as in the case of the syrups.

\section{Seismological Work at Stuttgart}

A VERY valuable addition to seismological data and an interesting addition to earthquake literature appears in the report of the Stuttgart Seismological Station for 1936, edited by Dr. W. Hiller, which has recently been received. The station is equipped with three Galitzin-Wilip seismographs orientated to record N.-S., E.-W., and vertical movement, two Mainka seismographs of mass $450 \mathrm{kgm}$. to read N.-S. and E.-W. vibrations, two vertical Wiechert instruments of mass $80 \mathrm{kgm}$. and $1,320 \mathrm{kgm}$. respectively, and one trifilar gravimeter. The report gives the readings of seismograms obtained with these instruments, including the phase, time of arrival, amplitude in the three components and remarks chiefly concerning the position of the epicentre of the shock which caused the record. At the end of the report are 15 pages of detailed study of earthquakes with epicentres in the neighbourhood of the station, including two sketch maps-one concerning the Bodensee earthquake of March 15, 1936, and one of the earthquake of April 19. 1936.

\section{Public Service Occupations}

A Bulletis entitled "Training for the Public Service Occupations" issued by the Office of Education, Department of the Interior, United States of America (Vocational Education Bulletin, No. 192. 20 cents) reviews the work already carried out in training for public service occupations below the university level. The Bulletin is concerned with the manual aspects of the public services rather than with the administrative side, and it is intended to interpret the provisions of the George-Deen Act as they relate to the promotion of vocational education for such occupations. It also outlines methods which have been used with success in planning and develop. ing training programmes, and indicates ways in which Federal, State and local trade and industrial educational agencies can assist in the organization of vocational training for such occupations. Incidentally, the Bulletin should serve a useful purpose in educating the general public in the work and problems of the public services, as has been done very successfully in Great Britain in certain civic exhibitions.

\section{New Antarctic Land}

IN a slender volume illustrated with photographs and maps, "My Last Expedition to the Antarctic, 1936-1937" (Oslo : Johan Grundt Tanum, 1938), Mr. L. Christensen has recounted all too briefly the voyage of the Thorshavn to the Wilkes Land and Enderby regions of the Antarctic. A brief voyage resulted in important work largely through the help of flying. In Lars Christensen and Ingrid Christensen Lands (Kemp and MacRobertson Lands) the mountain ranges were photographed and mapped. The most important discovery, however, was that of the 'missing' land between Crown Prince Olav and Princess Ragnhild Land, where from $34^{\circ}$ to $40^{\circ} \mathrm{E}$. Prince Harald Land was found from the air. A long range of mountains was noted in the interior. Thus practically the entire coast line of Antarctica from the Weddell Sea eastward to the Ross Sea is now known, and it would appear that in many parts mountains arise through the ice-sheet at greater or less distances from the coast. In several parts, rocky coasts or outlying islands suggest landing places for ground work. Mr. Christensen brought back geological specimens from several of his landings, but he says nothing of their nature.

\section{Communication Equipment for Vehicles}

To the A.W.A. Technical Review, published by the Amalgamated Wireless (Australasia), Ittd., of July, Dr. G. Builder and J. D. Gilchrist have contributed a paper on communication equipment for vehicles. Since about 1924, specific instructions for one or more units has been effected extensively either by radio telegraphy or telephone broadcasting. This only needed the fitting of receivers in the fleet units; the reports back to the organization headquarters being made when necessary by the ordinary telephone service. The advantages of two-way transmission led very soon to the use of telegraphic transmission from the units to headquarters when it was necessary to acknowledge instructions and make reports. This as a rule required trained radio operators both on the units and at headquarters. As development progressed, the use of telephony rapidly became common and duplex working was adopted. The improvement in the equipment has now made such services almost equivalent to the normal wire-line telephone services. In some cases it is possible to dial any one mobile unit from headquarters, causing a bell to ring in the mobile installation. The personnel of the mobile units, therefore, have not to keep continual watch and are not distracted by calls which do not concern them. It is feasible to arrange a dialling number calling either all the units or a group of them simultaneously. These highly developed systems are rare, but they indicate the inevitable trend of development in the near future. The use of crystal control of transmitter and receiver 